\title{
Nepalese Culture
}

Vol. XIII : 43-56, 2019

Central Department of NeHCA,

Tribhuvan University, Kathmandu, Nepal

\section{दशमहाविद्या एक परिचय}

\section{निर्मला पोखरेल}

\section{लेखसार}

नेपाली समाजको धार्मिक, सांस्कृतिक एवं सामाजिक परंपरामा वैदिक मूल्य, मान्यता र आदर्शको जति नै प्रभाव तात्तिक मूल्य मान्यता र आदर्शको पनि रहेको छ। यहाँ नैगमिक(वैदिक) र आगमिक(तात्त्रिक) दुवै परंपराको समन्वय भेटिन्छ। सुक्ष्मरुपमा विचार गर्दा नेपाली समाजमा तन्त्र एवं तन्त्रवादको अभक वढि प्रभाव रहेको पाईन्छ। यहाँका धार्मिक एवं सामाजिक परंपरा र रीतिरिवाजहरु आगम वा तन्त्रबाट नै बढि निर्देशित रहेका छन्। यसै परिप्रेक्षमा शाक्ततन्त्र परंपरा यहाँको प्रमुख तन्त्र परंपरामा पर्दछ। सम्पूर्ण विश्वब्रहमाण्डको परमकारणका रुपमा शक्ति अर्थात मातृदेवीलाई मानी तदनुरुप उपासना पद्धतिहरु प्रतिपादन गरिएका तन्त्रहरु शाक्ततन्त्र अन्तर्गत पर्दछन ।

देवताहरुको सर्वोच्च देवत्व शक्तिमा नै निहित भएको मानिन्छ। शिव, विष्णु लगायत अरु देवता पनि शक्तिको उपस्थिति विना क्रियाशील हुन सक्दैनन् । शक्तिले देवीदेवता र प्राणीलाई जन्म दिई शक्तिको संचार गर्ने हुनाले उनलाई स्त्रीरुपमा कल्पना गरिन्छ र आमाको स्थान दिईन्छ। शक्ति सर्वव्यापी तत्व हो र उनी व्रम्हा, बिष्णु, शिव आदिकी शक्ति भएकीले ती विश्वशक्तिको नाम भगवती पनि रहनगयो। प्राचीन समय देखि अस्तित्वमा रहेका शक्तिस्वरुपिणी देवीहरुलाई राजा गुणकामदेव (एघारौ शताव्दि)ले पुन : प्रशिद्ध वनाएको पाईन्छ। यस्ता देवीका विभिन्न स्वरुपको उपासना गर्ने कममा दशमहाविद्यारुपी देवीहरुको पूजा उपासना गर्ने परंपराको व्यापकता नेपालमा मध्यकालदेखि विषेशरुपमा रहेको पाईन्छ।

शब्दकुज्जिका : शाक्तधर्म, मातृशक्ति, तन्त्र, दशमहाविद्या, सतीदेवी, तान्त्रिक्रन्थ, मातृका, पन्चमकार

\section{परिचय}

देवी वा मातृशक्तिलाई विश्वव्रहम्माण्डको एकमात्र परमकारण मान्दै उनलाई नित्य, शाश्वत तत्वका रुपमा उपासना गर्ने धार्मिक सम्प्रदाय शाक्तसम्प्रदाय हो। समाजशास्त्री तथा पुरातत्वविद्हरुको मतमा परिवार तथा समाजको आविर्भाव एवं प्रारम्भिक गठनमा आमाको रुपमा नारीले महत्वपूर्ण भूमिका निर्वाहा गरेकाले विश्वका विभिन्न भागमा मातृसत्तालाई महत्वपूर्ण शक्तिकोरुपमा लिईएको र यसैको परिणामस्वरुप 
मातृशक्तिकोरुपमा देवीपूजाको प्रचलन प्रारम्भ भएको मानिन्छ। खासगरी मानवतामाथि परेको कष्ट, आपत र सङूटको क्षणमा शक्तिको आराधना गर्ने र शक्ति अनुकम्पाबाट कष्ट निवारण भएको उल्लेख प्राचीन धर्मग्रन्थहरुमा पाइन्छ।

शक्ति वस्तुत :एउटै छ, अद्वितीय छ, तर आफू एउटै भएर पनि भिन्नभिन्न कार्य गर्ने गराउने अलग अलग शक्तिका रुपमा प्रकाशित हुन्छ, र प्राणीका सवै कार्य सम्पन्न हुन्छन् (उपाध्याय, वि.सं. २०७४ पृ. १)। 'शक्तिकागमसर्वस्व' नामक ग्रन्थ, शंकराचार्यको सौन्दर्यलहरी लगायतका पुस्तकहरुमा शिव स्वयंले आफूलाई शक्तिले गर्दा अथवा शक्ति भएर नै म शिव भएको हूँ, शक्ति विना त म शव वा मुर्दा मात्र हूँ र स्पन्दन पनि गर्न सक्दिन भनिएको कुरा उल्लेखित छ (उपाध्याय, वि.सं. २०७४ पृ. १)। प्राचीन समयमा शक्तिको माहात्म्यको वर्णन गर्दे मार्कण्डेय पुराण अन्तर्गतको देवीमहात्म्य शप्तशती खण्डमा शक्तिलाई साक्षात् भगवती देवीको स्वरुप मानेर यसो भनिएको छ -

'या देवी सर्वभूतेषु शक्तिरुपेण संस्थिता ।

नमस्तस्यै नमस्तस्यै नमस्तस्यै नमो नमः ॥ १२' (वसिष्ठ, वि.सं. २०४७ पृ. ૪६३)।

अर्थात जुन देवी सवै प्राणीमा शक्तिरुपले स्थित छिन् उनलाई नमस्कार छ, नमस्कार छ, नमस्कार छ।

\section{नेपालमा शाकधर्म}

नेपालमा मातृशक्तिको उपासना परंपरा ज्यादै प्राचीन रहेको पाईन्छ। यो भूमी महादेव पार्वतीको विचरणस्थल रहेको र शाक्तधर्मकी अधिष्ठात्री देवी हिमालय पुत्री पार्वती; दुर्गा, काली, भगवती, चण्डिका, अम्विका आदि रुपले पुजिएको चर्चा पुराणहरुले गरेका छन्। यसै परिप्रेक्ष्यमा सतीदेवीका अड्नहरु खस्ने क्रमा सवैभन्दा पहिले गुह्य पतन भएको र उक्त गुह्य अंग वाग्मतीको किनारामा मृगस्थलीको उत्तरतर्फ खसेको र त्यो ठाउँ अत्यन्त ठूलो पीठ वनेको कुरा शिवले पार्वतीलाई वताएको उल्लेख नेपालमाहात्म्यमा गरिएको छ, (रेगमी, वि. सं. २०४३३ पृ. १४४) । यसप्रकार यो भूमि शिव पार्वतीले विचरण गरेको कीडास्थलको रुपमा प्रसिद्ध क्षेत्र हो ।

पुरातात्विक प्रमाणको आधारमा नेपालको पश्चिम तराईमा पर्ने वन्जाराहीको उत्वनन्मा प्राप्त माटाको नारी मुखौटा लाई ई.पु. पाँचौं छैटौं शताव्दीको हुनसक्ने र कपिलवस्तु उत्वनन्मा प्राप्त माटाका स्त्री मुर्तिहरुलाई ई.पु. प्रथम शताव्दी तिरको हुनसक्ने मानिएको छ (वाङ.देल, वि.सं. २०३९ पृ. २६-५३)। यसरी हेर्दा यहाँ देवीको पूजा ई.पु. पाँचौं छैटौं शताब्दी देखि नै गर्नथालिएको देखिन्छ। काठमाण्डौ उपत्यकामा प्राप्त मातृकाका मूर्तिहरु हेर्दा यहाँ शक्ति उपासनाको परम्परा ई.पू. देखि नै प्रचलनमा रहेको देखिन्छ, पाटन च्यासलहिटीको गजलक्ष्मी (प्रथम शताव्दी), वालाजुकी हारती / शितला ई.दोश्रो शताव्दी (वाङदेल, १९९५ पृ. ९३), चाँगुनारायण प्राड़णको छिन्नमस्ता मन्दिर भित्रका, कीर्तिपुर वाघभैरव मन्दिर प्राड़णका, मालीगाउँका, हाँडीगाउँ सत्यनारायण प्राड़णका मातृकाहरु, हाँडीगाउँ कोटालटोल (कार्तिकेय मन्दिर अगाडि दायाँ पद्टि) की षष्ठीदेवी दोश्रो शताव्दी (खनाल, बि.सं. २०४२ पृ. १६), हाँडीगाउँ धनगणेश मन्दिरभित्रकी महिषासुरमर्दिनी दुर्गा तेश्रो शताव्दि (वाङदेल, १९९५ पृ. 
११३) जयवागेशरी मन्दिर भित्रका, हौगल वहालकी, वल्खुमा प्राप्त मातृका, कुम्भेश्वर वगलामुखी मन्दिरभित्रका मातृकाहरु, लगायतका देवीहरु ई.दोश्रो तेश्रो शताव्दीका हुन् भने राष्ट्रियनाचघर प्राङुणमा रहेको व्रम्हादिचतुर्मूर्ति तेश्रो शताव्दीको अन्त्य र चौथो शताव्दीको शुरुवातको मानिन्छ, जसको उत्तरी पाटोमा देवीको मूर्ति रहेको छ, भने पूर्वी पाटोमा ब्रम्हा, पश्चिममा विष्णु, दक्षिणमा शिव रहेका छन् (प्रत्यक्ष अवलोकन)। त्यसैगरी कमलादी गणेशस्थान भित्रका वैष्णवी, वाराही, कौमारीका मूर्तिहरु पाँचौं शताव्दीका का हुन् (वाङदेल, १९९५ पृ. १३३)। अभिलेखीय प्रमाणको आधारमा सम्वत ४२५ (वि.सं. पू६०) को राजा मानदेवको शासनकालमा पलाज्चोक भगवती स्थानमा रहेको अभिलेखमा सम्राट गृहपतिकी पत्नी विजयस्वामिनीले भगवती विजयेश्वरी देवीको प्रतिष्ठा गरेको उल्लेख छ (वज्राचार्य, वि.सं. २०५३ पृ. ६७)। लिच्छविकालमा पाईएको शाक्त सम्प्रदाय सम्बन्धी यो पहिलो अभिलेख हो। यसवाट राजा मानदेवको समयमा नै शाक्त सम्प्रदायले दह्रो जरा गाडिसकेको अभिलेखीय प्रमाण पाईन्छ। यस्तै पाटन सिकुवहीको संवत् ४९५ (वि.सं. ६३०) को अभिलेखमा उल्लेख भएअनुसार वाग्वती र मणिमतीको दोभानमा माटाका मातृकाका मूर्तिहरु रहेकोमा कालक्रमले पुराना भएर ज्यादै जीर्ण भए त्यसैले त्यो ठाउँमा अर्के किसिमले ढुड़े मातृका देवीहरु वनाईए भनिएको छ (वज्राचार्य, वि.सं. २०५३ पृ. २१२)। यसवाट यो भन्दा सयौ वर्ष अगाडि नै यहाँ मातृका देवीहरु स्थापित भईसकेको प्रष्ट हुन्छ। यसरी नै अंशुवर्माको संवत् ३० (वि.सं. ६६४) ज्येष्ठको हाँडीगाउँको अभिलेखमा श्रीदेवीलाई ३ पुराण 9 पण, षष्ठीदेवकुललाई ३ पुराण $१$ पण छुट्याइएको उल्लेख छ (वज्राचार्य, वि.सं. २०५३ पृ. ३०२)। यहाँ श्रीदेवी भन्नाले ईष्टदेवी हुनसक्नेकुरा वज्राचार्य वताउनु हुन्छ। वहाँको विचारमा कवि वाणले कादम्वरीमा राजाको दिचर्याको चर्चागर्दा सर्वप्रथम उनले इष्टदेवताको पूजा गर्थे भनेका छन् र यहाँ पनि अभिलेखमा सवै भन्दा पहिला श्री देवीलाइ भाग छुट्याईएकोले वज्राचार्यले श्री देवीलाइ ईष्टदेवी हुनसक्नेकुरा उल्लेख गर्नु भएको हो (वज्राचार्य, वि.सं. २०४३३ पृ. ३०४)। सामान्य प्रचलनमा भने श्रीदेवी भन्नाले लक्ष्मी भन्ने वुकिन्छ। त्यसैगरी यो अभिलेखमा उल्लेखित षष्ठीदेवी मातृका विशेष हुन् जुन षोडशमातृकाहरुमध्ये एक हुन् र यिनी वच्चाको छैठी गर्दा पूजिने मुख्य देवी पनि हुन् (लामिछाने, २०७३ पृ. ५९)। कवि वाणले कादम्वरीमा राजदरवार भित्र षष्ठीदेवीको पूजा हुन्थ्यो भनि उल्लेख गरेका छन् । षष्ठीदेवी 'सिठी' देवताको पूर्वरुप हो र नेपालमा मध्यकाल र वर्तमान सम्म पनि सिठीपर्व राष्ट्ररक्षा आदिको दृष्टिले महत्वपूर्ण पर्व मानिन्छ। काठमाडौं उपत्यकामा जैसीदेवलनेरको 'सिठी' देवताको मन्दिर केही प्रशिद्ध रहेको छ (वज्राचार्य, वि.सं. २०४३ पृ. ३०४)। हाल सम्म पनि उक्त मन्दिरको अस्तित्व रहेको पाईयो (प्रत्यक्ष अवलोकन) ।

लिच्छवि कालका अभिलेख सहित र रहितका दर्जनौ देवीका मूर्तिहरु अभैसम्म उपत्यकामा यत्रतत्र छरिएर रहेका छन् । जसमध्ये पशुपतिनाथस्थित वनकालीमा रहेको वनकाली देवीको मूर्तिमा ' ...सान्य: ककशारिः सोमोमच्व: दतनिति 'अंकित अंशुवर्माकालीन लिच्छवि अभिलेख रहेको छ (वज्राचार्य, वि.सं. २०४३ पृ. ५९७)। त्यसैगरि पशुपति क्षेत्रमा रहेको जयवागीश्वरी मन्दिर भित्रको जयवागीश्वरीदेवीमूर्तिको पादपीठमा 'गुहसोम ... वृद्धिको यो कृति हो' भनि लिच्छवि लिपिमा लेखिएको छ (वज्राचार्य, वि.सं. २०४३ पृ. पू६३) । यी वाहेक राष्ट्रिय संग्रहालय छाउनीमा रहेको पद्महस्तालक्ष्मी (सातौं शताव्दि), पाटन चपटोलको हारितीलाई वाङदेलले ७-६ शताव्दिको मान्नु भएको छ (वाङदेल, १९६२ पृ. १४५)। नक्शाल भगवती, शोभा भगवती 
अन्तिम लिच्छविकालमा निर्मित मूर्तिहरु हुन् । यसप्रकार नेपालको प्रामाणिक इतिहास संगै यहाँ मातृकाका मूर्तिहरु प्रमाण सहित प्रशस्त प्राप्त भएका छन् ।

पूर्वमध्यकालमा पनि शाक्तउपासना ज्यादै प्रचलित रहेको कुरा उपत्यकामा प्राप्त मन्दिर, मूर्ति र अभिलेखहरुले दिएका छन्। यसै सन्दर्भमा पूर्वमध्यकालका राजा गुणकामदेव (एघारौ शताब्दी)ले देश रक्षाको निम्ति काठमाण्डौको चारैतिर अष्ठमातृकाहरु स्थापना गरेको कुरा देवमाला आदि वंशावलीमा उल्लेखित छ, (रेगमी, १९६६ पृ. पू७९-६२) जुन निम्नानुसार रहेका छन् - १) कमलादीको रुद्रायणी (पासिको अजीमा) २) भद्रकालीको ब्रम्हायणी (लुमणी अजीमा/ओचु अजीमा (ओचु =नीलो), ३) काठमाण्डौ टुँडीखेलको कौमारी पीठ (फीवो/फिफु अजीमा) $\gamma$ ) पचली भैरव छेड्को वैष्णवी पीठ (पचली अजीमा) $y$ ) विष्णुमती किनार, डल्लु वारीकी वाराही (कंकेश्वरी अजीमा) ६) शोभा भगवती वारी ईन्द्रायणी (लुती अजिमा) ७) मैपीस्थित चामुण्डा (मैपी अजीमा) ६) नारायणहिटी दरवार कम्पाउण्ड भित्रको महालक्ष्मी पीठ (श्री/चन्द्र अजीमा) (रेग्मी, १९६६ पृ. पे७९-६२)। यही कुरा पासिको अजीमा पीठका पुजारी, देवनारायण महर्जन, वर्ष-प९ ले पनि वताउनु भयो।

मेरी श्लसरका अनुसार पनि मातृकाहरुको मुख्य भुमिका भनेको नेपालमण्डलको संरक्षकको रुपमा देखिन्छ र उनीहरुलाई आठै दिशाका दिक्पाल सरहको मर्यादा प्राप्त भएको पाईन्छ। उनीहरुसंग सम्वन्धित ‘ दिसिपूजा' वाट पनि यो प्रष्ट हुन्छ, आठवटी मातृकाहरुलाई आठ दिशा पूर्व, पश्चिम, उत्तर, दक्षिण, आग्नेय, नैऋत्य, वायव्य, ईसानका स्वामी वनाईएको पाईन्छ ( श्लसर, १९६२ पृ. ३४४)। गोपीनाथ रावका अनुसार मातृकादेवीहरुलाई आठै दिशाका ‘दिक्पाल’ का रुपमा पूजा गर्ने परम्परा भारतमा पनि रहेको वताएका छन् (राव, १९६द प्. ३५६)। नेपालको सन्दर्भमा भने विशेष गरेर मातृकाहरुको उपासना प्राकृतिक प्रकोपहरुवाट वच्न, युद्धमा विजय हाँसिल गर्न, रोगब्याधी पन्छाउन, ग्रहहरुको शान्तिको लागि साथै संरक्षीकाको रुपमा पनि गरिन्छ।

राजा जयस्थिति मल्ल मनमानेश्वरी देवीका परम भक्त थिए र उनले 'श्रीमनमानेश्वरीवरलव्धप्रशाद' उपाधि धारणगरी आफूलाई शक्तिका उपासक मानेको कुरा ने.सं. पू६ को पशुपति जयवागीश्वरीको सुनधारा (ढुड़ेधारा)को अभिलेख (वज्राचार्य, वि.सं. २०६६ पृ. १७३) र पशुपति नाथ मन्दिरको पश्चिमी प्राड़णमा लहरै रहेको अभिलेखहरु मध्येको ने.सं. पू३३ को अभिलेखमा उद्गृत गरेका छन् (वज्राचार्य, वि.सं.२०६६ पृ. २३६)। फर्पिड भेगका स्थानीय शासक जयजैत्रसिंहदेवले पनि 'श्रीश्रीभंकेश्वरीवरलव्धप्रशादेत्या' उपाधि धारण गरेको कुरा फर्पिड वजारको कोछुटोल को कड़ेश्वरी मन्दिरमा रहेको ने.सं. पू२७ को अभिलेखमा उल्लेखित छ (वज्राचार्य, वि.सं. २०६६ पृ. २१४)।

राजा ज्योतिर्मल्लले पनि 'श्रीश्रीमानेश्वरीवरलव्धप्रशादित' भन्ने उपाधि धारण गरेको कुरा ललितपुर इवावहीको भगवान मन्दिरको ढोका माथि रहेको ने.सं. पू४७ को उनको अभिलेख ( वज्राचार्य, वि.सं.२०६६ पृ. २७७) र उनैको ने.सं. पू३६ को पशुपतिकोनाथको नैत्यत्यकोण पद्टि रहेका लहरैका अभिलेख मध्ये एकमा आफुलाई 'श्रीश्रीमानेश्वरीवरलव्धप्रशादित' भनेकोवाट थाहा पाईन्छ, (वज्राचार्य, वि.सं. २०६६ पृ. २६०) । उनैका छोरा राजा यक्ष मल्लले 'श्रीमन्मानेश्वरीदेवीवरलव्ध' उपाधि धारण गरेको कुरा ने.सं. पूरद को ठिमी वहालटोलको शिवालयको अभिलेखमा उल्लेखित छ (वज्राचार्य, वि.सं. २०६६ पृ. २९०)। 
यी वाहेक यो कालमा अरु पनि धेरै देवीहरुका मूर्ति, मन्दिरहरु स्थापित भएको पाईन्छ। मध्यकालमा पनि सयौंको संख्यामा स्थापित देवीहरुका मूर्ति, मन्दिरहरु आजसम्म हाम्रा सामु यत्रतत्र छरिएर रहेका छन् । यो कम शाहकालमा र हालसम्म पनि चलिनै रहेको छ।

\section{तन्त्र}

दशमहाविद्या तात्त्रिक देवीहरु भएको कारणले यहाँ तन्त्रको सामान्य चर्चा गर्न जरुरी देखिन्छ। यसै परिप्रेक्षमा तन्त्र, मन्त्र, जादु, टुना, भय, आशंका, इच्छा इत्यादि मानव इतिहास जत्तिकै पुराना कुरा हुन् र यिनैको आधारमा पछि, तन्त्रशास्त्र लेखियो भनी लैनसिंह वाङुदेल धनशमशेर जवरा लिखित मातृकाक्षररहस्यम् नामक पुस्तकको मन्तव्य लेख्ने कममा भन्नुहुन्छ (जवरा, बि.सं. २०३० पृ. छैन)। वैदिक कालदेखि नै तन्त्रको सूत्रपात भैसकेको अध्ययनले देखाउँछ। वेदले ठाउँ-ठाउँमा आगम वा तन्त्रका मन्त्रहरुको वर्णन र तन्त्रले ठाउँ-ठाउँमा वेदका मन्त्रको वर्णन, फेरि दुवैले ऊँ-कारको वर्णन गरेवाट यी दुवै समकालीन भएको सावित हुन्छ भनी जवरा लेख्नुहुन्छ -

"नवेद:प्रणर्व त्यक्त्वा मत्त्रो वेदसमन्वितः।

तस्माद्वेदपरो मन्त्रो वेदांगश्चागम:स्मृतः ॥” (जवरा, बि.सं. २०१६ पृ. २)।

उहाँ अनुसार “राम्ररी अध्ययन गरेर तन्त्रशास्त्रको खोजी गरेको खण्डमा यसमा जे खोजे पनि पाईन्छ, यसलाई एक प्रकारको मनचिन्ते कोला भने पनि हुन्छ। यसवाट वैदिक कालदेखि हालसम्म आर्यहरुको धर्म, कर्म, संस्कृति, व्यवहार र परम्परा तथा रहनसहन औ चालचलन सवैको अध्ययन हुन्छ" (जवरा, बि.सं. २०१५ पृ. ४)। ॠषि भारद्वाजले तन्त्रको परिभाषा आफ्नो 'यन्त्रार्णव' नामक ग्रन्थमा यसरी गरेकाछन् “मानवीपाशवीशक्तिकार्य तन्त्रमिति स्मृतम्” अर्थात मानवी भन्नाले मान्छेको शक्तिको साथमा, पाशवी भनेको 'पाश' नामको अलौकिक शक्तिवाट हुनसक्ने जुन कार्य छ त्यसैलाई 'तन्त्र' भनिन्छ (प्रपन्नाचार्य, वि.सं. २०७५ पृ. २२९)। यसै परिप्रे क्षमा भारद्वाजले मन्त्र र यत्त्रको पनि परिभाषा गरेका छन्, उनी अनुसार मन्त्र भन्नाले- जल र वायु दुवैलाई स्तम्भन गरेर अर्थात विधिले रोकेर जुन शक्ति उत्पन्न हुन्छ त्यसलाई मन्त्र भनिन्छ र यन्त्र भन्नाले -दण्ड, चक्र, आरा जस्तो दाँत भएको सर्किने, घुम्ने, वरतिर परतिर, तलमाथि आदिद्वारा जुन शक्तिको बर्द्धन र संचालन हुन्छ त्यसलाई 'यन्त्र' भनिन्छ (प्रपन्नाचार्य, वि.सं.२०७४ पृ. २२९)। चूडानाथ भट्टराय, धनशमशेर जवरा लिखित ' मातृकाक्षररहस्यम्' पुस्तकको भूमिका लेख्ने कममा भन्नुहुन्छ - "मातृकावर्णभेदेभ्य:सर्वे मन्त्राप्रजजिरे" अर्थात मातृकावर्णभेदबाट सवै मन्त्र जन्मन्छन, (जवरा, बि.सं. २०३० पृ. छैन)।

धेरैजसो सन्धर्भमा तन्त्र, मन्त्र र यन्त्र शव्दको प्रयोग संगसंगै आउने गर्दछ् ।

पूर्ववैदिक काल आदिशिवसंग सम्वद्ध मानिन्छ र तिनै आदि शिव र वैदिक युगका रुद्र; शैव तथा शाक्ततन्त्रका मूल श्रोत मानिन्छन् (बनर्जी, १९६६ पृ. ६३)। त्यसपछि, पनि लगातार पछिल्ला वैदिक साहित्यहरु, धर्मशास्त्र एवं पुराण, महाकाव्य आदिमा पनि तन्त्रको चर्चा भई नै रहेको पाईन्छ। हिन्दु धर्मशास्त्र अनुसार ज्ञानको विस्तारलाई तन्त्र भनिन्छ र यसको शुरुवात शिववाट भएको मानिन्छ (शर्मा, १९९९ पृ. ४६९)। 
वास्तवमा मानवीय जीवनका विभिन्न व्यवहारिक प्रयोगहरुलेयुक्त लौकिक एवं अलौकिक सिद्धि प्राप्त गर्ने उपाययुक्त साधनाशास्त्र नै तन्त्र हो । तन्त्रले जीवन र जगतलाई यथार्थ मान्ने हुनाले तन्त्रवादको मूल स्वभाव सांसारिक कृयाकलापको विस्तार गर्दे सोही कृयाकलापमा भोग र मोक्षको वाटो देख्नु हो भन्ने बुकिन्छ । देवी, भूत, प्रेत, मशान र जादुसँग सम्वन्धित मन्त्रलाई पनि तन्त्र भनिन्छ। मारण, मोहन, उच्चाटन, वशीकरण, कार्यसिद्धि र रक्षाको लागि तन्त्रको प्रयोग गरिन्छ। तन्त्रशास्त्र अनुसार कलियुगमा वैदिक मन्त्र, जप र यज्ञाट फल प्राप्त नहुने र यस युगमा कार्यसिद्धिका लागि तन्त्र नै सवैभन्दा महत्वपूर्ण मानिने अवधारणा छ।

\section{तन्त्रपरंम्परा}

नेपाली समाजमा वैदिक(नैगमिक) मुल्य, मान्यता जति कै तात्त्रिक (आगमिक) मुल्य, मान्यता पनि रहेको छ र यो मान्यता नेपाली समाज जति नै पुरानो हो । यहाँ मनाउने चाडपर्वहरु, विभिन्न जातिका संस्कारहरु, विभिन्न सम्प्रदायका धर्महरु, पुजाआजा सवैमा कुनै न कुनै रुपमा तन्त्रको अस्तित्व रहेको पाईन्छ। सोही परिप्रेक्षमा धनशमशेर जवरा लिखित तन्त्र-शास्त्र नामक ग्रन्थको परिचय दिने ऋममा वालकृष्ण सम भन्नुहुन्छ, "हिजो आजको नेपालमा जुन कला र संस्कृति छन्, दैनिक जीवनमा जुन जात्रा-मात्रा अनि चाडपर्व देखिइन्छन् ती केही हिन्दु पौराणिकतामा आधारित छन् तर मुख्यत ती तात्त्रिक नै हुन्, मन्दिर-मन्दिर, घर-घर, वाटो-वाटोमा हामी हाम्रो तन्त्र पाउँछौं यहाँ इन्द्र, रुद्र वा विष्णु सवै वैदिक रुपमा होईन तात्त्रिक रुपमा छन् र यीनै हाम्रा मौलिक संस्कृति कला र गौरव हुन्” (जवरा, बि.सं. २०१५ पृ. ७)। तन्त्रात्मक क्रियाकलापको पृष्ठभूमिमा परम्परागत जनविश्वास, लोकधारण, अलौकिक सत्ताप्रतिको विश्वास, भौतिक सुखको साथै अभौतिक सुखको कामना जस्ता कुराहरु रहेका हुन्छन्।

तन्त्रपरम्परालाई मुख्यतः दुई वर्गमा विभाजन गर्न सकिन्छ -

१. लिखित तन्त्रपरम्परा २. अलिखित तन्त्रपरम्परा

\section{लिखित तन्त्रपरम्परा}

लिपिवद्ध तन्त्रपरम्परा लिखित तन्त्रपरम्परा हो र यसलाई मुख्यत : ७ वर्गमा विभाजित गरिएको छ। ती हुन्-

१) शैवतन्त्र २) शाक्ततन्त्र ३) वैष्णवतन्त्र

४) गाणपत्यतन्त्र ६ ) सौरतन्त्र ६) बौद्धतन्त्र ७) जैनतन्त्र (लामिछाने, वि.सं. २०७३ पृ. २३)।

\section{अलिखित तन्त्रपरम्परा}

अलिखित तन्त्रपरम्परा लिपिवद्ध छैन यस अन्तर्गत धामी, भाँकी, रोजा आदिले श्रुति परम्पराका आधारमा जीवित राखेको र आफ्ना जातीय संस्कार, परम्परा, पूजाआजा आदि सम्पन्न गर्दा प्रयोग गर्ने गरेको पाईन्छ।

यिनिहरु मध्ये शाक्ततन्त्रको यहाँ चर्चा गरिन्छ - 


\section{शाक्ततन्त्र}

शाक्ततन्त्रअन्तर्गत विश्वब्रह्माण्डको परम कारणको रुपमा मातृदेवी अर्थात शक्तिलाई मान्ने र सोही अनुरुप उपासना पद्दतिहरु प्रतिपादन गरिएका तन्त्रहरु पर्दछ् । शिव र शक्तिलाई अभिन्न मान्ने शाक्ततन्त्रमा तात्विकदष्टिले यी दुई बीचमा खासै भिन्नता पाईदैन। फरक भनेको शैवतन्त्रमा शिवलाई सर्वोच्च उपास्यकारुपमा कल्पना गरिएको हुन्छ भने शाक्ततन्त्रमा शक्तिलाई ।

शाक्ततन्त्रअन्तर्गत विषेश गरेर दशमहाविद्या लगायतका अरु पनि देवीहरुको साधना गरी जीवनमा आईपर्ने विभिन्न कष्ट र समस्याहरुको निराकरण गरी अभीष्ट पूर्ति गर्ने र आफ्नो रक्षा पनि गर्ने चाहना राखिएको हुन्छ। हिन्दू तात्त्रिक ग्रन्थ अनुसार तन्त्र साधना गर्ने सिद्ध तीन प्रकारका हुन्छन्-उत्तम, मध्यम् र अधम । उत्तम वर्गको सिद्ध मनोवाज्छित वस्तुको प्राप्ति मनमा इच्छा लागने वित्तिके पूरा गर्न समर्थ हुन्छन्। मध्यम् वर्गका सिद्ध द्यौतासंग साक्षात्कार भै कुरा गर्ने, अर्काको घरमा वा शरीरमा अदृश्य भै प्रवेश गर्ने ,मान्छेलाई मन्त्रमुग्ध पार्ने, दृष्टिले मात्रै पनि रोगव्याधी निर्मूल पार्ने, सवै शास्त्रमा पारंगत हुन्छन् भने अधम वर्गका सिद्धको भने चमत्कारी क्षमता सीमित हुन्छ र भौतिक स्वभावको हुन्छ, जस्तो मानिसहरुलाई आफ्नो कावुमा पार्ने, राज सम्मान हत्याउने, नाम कमाउने ,सम्पत्ति जोड्ने जस्ता कार्यमा सिपालु मानिन्छन् त्यसैले यिनीहरुलाई उत्तम वर्गका सिद्धहरुले सिद्ध पुरुष मान्दैनन् (दीप, वि.सं. २०४२ पृ. ४९ ) ।

शाक्ततन्त्रमा प्राचीन मूल चौसठी तन्त्र र उपास्यभेदमूलक तन्त्र प्रमुख छन् (लामिछाने, वि.सं. २०७३ पृ. २६)। यो वाहेक तेश्रो मतमूलक तन्त्र पनि पर्दछ। चौसठी तन्त्रको सूचीमा नामावली केही फरक-फरक पाईन्छ। शङ्कराचार्यद्वारा रचित सौन्दर्यलहरीमाथि भास्कररायले रचना गरेको सेतुवन्धनामक टीकाअनुसार चौसठ्ठी तन्त्रको नामावली यसप्रकार रहेको छ, (कविराज, १९७२ पृ. २४)।

\section{प्राचीन मूल चौसठी तत्त्र}

9) महामाया २) शम्वर ३) योगिनी ४) जालशम्वर दू) तत्वशम्वर ६) भैरवाष्टक ( ) ब्राहमी द) माहेश्वरी ९) कौमारी १०) वैष्णवी ११) बाराही १२) माहेन्द्री १३) चामुण्डा १४) शिवदुती १४) ब्रह्मयामल १६) विष्णुयामल १७) रुद्रयामल १६) लक्ष्मीयामल १९) उमायामल २०) स्कन्दयामल २१) गणेशयामल २२) जयद्रथयामल २३) चन्द्रज्ञान २४) वासुकि २६) महासम्मोहन २६) महोच्छुष्म २७) वातुल २६) वातुलोत्तर २९) हृद्भेद ३०) तन्त्रभेद ३१) गुट्यततन्त्र ३२) कामिक ३३) कलावाद ३४) कलासार ३४) कुब्जिकामत ३६) तन्त्रोत्तर ३७) चीनाख्य ३६) त्रोतल ३९) त्रोतलोत्तर ४०) पञ्चामृत ४१) रुपभेद ४२) भूतोड्डामर ४३) कुलसार ४४) कुलोड्डीस ४४) कूलचुडामणी ४६) सर्वज्ञानोत्तर ४७) महाकालीमत ४६) महालक्ष्मीमत

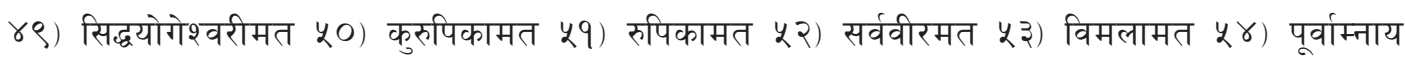
पूर) पश्चिमाम्नाय प६) दक्षिणाम्नाय पै७) उत्तराम्नाय पू) ऊर्धाम्नाय प९९) वैशेषिकतन्त्र ६०) ज्ञानार्णव ६१) वीरावली ६२) अरुणेश ६३) मोहिनीश ६४) विशुदेश्वर 


\section{उपास्यभेदमूलक तन्त्र}

उपास्य भेदको दृष्टिले शाक्ततन्त्र दशमहाविद्याका आधारमा दश प्रकारका रहेका छन् । जुन निम्नानुसार छन् (कविराज, १९७२ प्. २ू) :-

१) कालीतन्त्र २) तारातन्त्र ३) षोडशीतन्त्र ४) भुवनेश्वरीतन्त्र $y$ ) भैरवीतन्त्र ६) छिन्नमस्तातन्त्र ७) धूमावतीतन्त्र ५) बगलातन्त्र ९) मातड्रीतन्त्र १०) कमलातन्त्र

\section{i) कालीतन्त्र}

भगवती कालीलाई उपास्य मानेर रचना गरिएका सिद्धान्त तथा प्रयोगग्रन्थहरु कालीतन्त्र अन्तर्गत पर्दछ् । यसअन्तर्गत पर्ने मुख्य तन्त्रहरु यसप्रकार छन् - महाकालसंहिता, कालज्ञान, कालोत्तर, कालीयामल, कालीकल्प, कालीकुल, कालीपरा, कालीतत्व, कौलावली, कुलार्णव, कालीकार्चामुकुर, कालीकुलक्रमार्चन, भद्रकालीचिन्तामणि आदि मुख्य रहेका छन् (कविराज,.१९७२ पृ. २६-२७)।

\section{ii) तारातन्त्र}

भगवती तारालाई उपास्य मानेर रचना गरिएका सिद्धान्त तथा प्रयोगग्रन्थहरु तारातन्त्र अन्तर्गत पर्दछ् । यसअन्तर्गत पर्ने मुख्य तन्त्रहरु यसप्रकार छन् - तारिणीतन्त्र, तारासूक्त, तारार्णव, नीलतन्त्र, नीलसरस्वतीतन्त्र, तन्त्ररत्न, एकाजटीतन्त्र, तोडलतन्त्र, एकजटाकल्प, तारिणीपारिजात, तारिणीनिर्णय, ताराकल्पलतापद्दति, चीनातारा, महोग्रताराकल्प, महानीलतन्त्र आदि मुख्य रहेका छन् (कविराज, १९७२ पृ. २६)।

\section{iii) षोडशीतन्त्र}

भगवती षोडशीलाई उपास्य मानेर रचना गरिएका सिद्धान्त तथा प्रयोगग्रन्थहरु षोडशीतन्त्र अन्तर्गत पर्दछन् । यसअन्तर्गत पर्ने मुख्य तन्त्रहरु यसप्रकार छन् - श्रीविद्या, तन्त्रराज, मातृकावर्ण, योगिनीहृदय, त्रिपुरार्णव, चन्द्रज्ञान, सौभाग्यकल्पद्रुम, ज्ञानार्णव, सौभाग्यकल्पतालिका, सौभाग्यतन्त्रोत्तर, सौभाग्यरत्नाकर, सौभाग्यभास्कर, सौभाग्यचन्द्रोदय, सुन्दरीमहोदय, लक्ष्मीतन्त्र, श्रीविद्यारत्नसूत्र ,चन्द्रपीठ, ललितोपाख्यान, कामकलाविलास, आदि मुख्य रहेका छन् (कविराज, १९७२ पृ. २९-३७)।

\section{iv) भुवनेश्वरीतन्त्र}

भगवती भुवनेश्वरीलाई उपास्य मानेर रचना गरिएका सिद्धान्त तथा प्रयोगग्रन्थहरु भुवनेश्वरीतन्त्र अन्तर्गत पर्दछन् । यसअन्तर्गत पर्ने मुख्य तत्त्रहरु यसप्रकार छन् - भुवनेश्वरीरहस्य, भुवनेश्वरीतन्त्र, भुवनेश्वरी पारिजात आदि मुख्य रहेका छन् ।

\section{v) भैरवीतन्त्र}

देवी भैरवीलाई उपास्य मानेर रचना गरिएका सिद्धान्त तथा प्रयोगग्रन्थहरु भैरवीतन्त्र अन्तर्गत पर्दछ् । यसअन्तर्गत पर्ने मुख्य तन्त्रहरु यसप्रकार छन् - भैरवीतन्त्र, भैरवीरहस्य, भैरवीयामल, भैरवीसपर्याविधि आदि मुख्य रहेका छन् । 


\section{vi) छिन्नमस्तातन्त्र}

देवी छिन्नमस्तालाई उपास्य मानेर रचना गरिएका सिद्धान्त तथा प्रयोगग्रन्थहरु छिन्नमस्तातन्त्र अन्तर्गत पर्दछ् । यसअन्तर्गत पर्ने मुख्य तन्त्रहरु यसप्रकार छन् -शक्तिसंगमतन्त्र (छिन्नमस्ता खण्ड) र छिन्नमस्तातन्त्र मुख्य रहेका छन् ।

\section{vii) धूमावतीतन्त्र}

देवी धूमावतीलाई उपास्य मानेर रचना गरिएका सिद्धान्त तथा प्रयोगग्रन्थहरु धूमावतीतन्त्र अन्तर्गत पर्दछ् । यसअन्तर्गत पर्ने तन्त्रमा धूमावतीतन्त्र मुख्य रहेको छ। शत्रुलाई मारण, मोहन र उच्चाटन गर्नकालागि धूमावतीतन्त्रको उपयोग गरिन्छ (कविराज, १९७२ पृ. ३६)।

\section{viii) बगलातन्त्र}

देवी बगलालाई उपास्य मानेर रचना गरिएका सिद्धान्त तथा प्रयोगग्रन्थहरु बगलातन्त्र अन्तर्गत पर्दछ् । यी देवीको पूजा एवं प्रयोग सम्वन्धि मुख्य तन्त्र शाडखायनतन्त्र हो जुन षड्विद्यागम नामले प्रसिद्ध छ। बगलाकै विषयमा अर्को प्रसिद्ध तन्त्र बगलाक्रमकल्पवल्ली रहेको छ (कविराज, १९७२ पृ. ३६) ।

\section{ix) मातड़्रीतन्त्र}

देवी मातड़ीलाई उपास्य मानेर रचना गरिएका सिद्धान्त तथा प्रयोगग्रन्थहरु मातड़ीतन्त्र अन्तर्गत पर्दछन् । मतड्ग नामक ऋषिले उपासना गरेको हुनाले यीनलाई मातड़ी भनिएको हो। यसअन्तर्गत पर्ने तन्त्रहरुमा मातड्गीक्रम, मातड्गीपद्धति, सुमुखीपूजापद्धति आदि मुख्य रहेका छन् ।

\section{x) कमलातन्त्र}

कमला महाविद्यासँग सम्वद्ध तन्त्रग्रन्थहरुमा कमलात्मिकातन्त्र, लक्ष्मीतन्त्र आदि मुख्य रहेका छन् ।

\section{आचारका दृष्टिले शाक्ततन्त्रलाई तीन वर्गमा विभाजन गर्न सकिन्छ}

१. कौलतन्त्र २.मिश्रतन्त्र ३.समयतन्त्र

\section{कौलतन्त्र}

शाक्तहरुको वाम सम्प्रदायको एउटा शाखा कौलाचार हो । त्रिविध भाव दिव्य, घोर, पशु मध्ये दिव्यभावमा लीन सर्वत्र समान रुपले देख्ने व्यक्ति कौल हुन्छ र कौलहरुको वारेमा यस्तो कथन भएको कुरा हरेराम जोशी वताउनु हुन्छ - "भित्र शाक्त, बाहिर शैव, सभामा वैष्णव, यसरी नानारुप धारण गरी कौलहरु पृथ्वीमा विचरण गर्दछन्" (जोशी, वि.सं. २०७० पृ. २२३) । अर्थात कौलहरुलाई कुनै नियम र परिधिले बाँध्न सक्तैन, उ स्वतन्त्र छ उ कहिले शिष्ट र कहिले भ्रष्ट पनि हुन्छ। हिलो र चन्दन, छोरा र शत्रु, घर र श्मशानमा उसलाई भेद छैन। कौलसाधनालाई अध्यात्मसाधनाको क्षेत्रमा सवैभन्दा श्रेष्ठ मान्ने र ज्यादै निकृष्ट र जघन्य पनि मान्ने दुवै धारणाहरु विद्यमान छन् । मूलका रुपात्मक मात्र रहेका पन्मकार मद्य, मांस, मत्स्य, मुद्रा ,मैथुन 
लाई पछि गएर कौलहरुले भौतिक रुपमा नै प्रयोग गर्नथाले (जोशी, वि.सं. २०७० पृ. २२३)। कौलाचार सजिलै प्राप्त गर्न सकिदैन, पूर्वजन्म देखि नै साधना गरेको साधकले मात्र यो अवस्था प्राप्त गर्दछ भन्ने मान्यता छ । कौलाचारसंग सम्वद्ध प्रमुख तन्त्रग्रन्थहरु यसप्रकार छन् - कुलार्णव, कुलचुणामणी, भावचुणामणी, कुलतन्त्र, उत्तरतन्त्र, तन्त्रचुणामणी, कुलयामल, कुलमत, कौलतन्त्र, कुलावातार, कौलमार्ग, कौलरहस्य, कौलोपनिषद, कुलशासन, वामकेश्वरतन्त्र, परशुरामकल्पसूत्र, शाम्भवितन्त्र आदि मुख्य रहेका छन् (कविराज, सन् .१९७७ पृ. ४५-૪६)।

\section{मिश्रतन्त्र}

कौलाचार र समयाचारको मिश्रित स्वरुपमा मिश्राचारको प्रादुर्भाव भयो। कौलाचार वाममार्ग हो भने समयाचार वैदिकमार्ग वा दक्षिणमार्ग हो। यी दुवै आचारको मिश्रित आचार नै मिश्राचार हो। यो आचारसंग सम्वन्धित तन्त्रहरु यसप्रकार छन् - कुलार्णव, चन्द्रकला, कलानिधि, कुलेश्वरी, ज्योत्स्नावती, भुवनेश्वरी, वार्हस्पत्य र दुर्वासामत ।

\section{समयतन्त्र}

समयचारमा शक्तिको पूजा वेदानुकूल गरिन्छ। समयाचारसंग सम्वद्ध तन्त्रहरु समयतन्त्र अन्तर्गत पर्दछन् र यिनीहरु पाँचको समुहमा रहेका छन् जसलाई शुभागमपन्चक भनिन्छ। यिनका नामहरु यसप्रकार रहेका छन् - क).वसिष्ठसंहिता, ख).सनकसंहिता, ग).शुकसंहिता, घ).सनन्दनसंहिता ङ). सनत्कुमारसंहिता

वास्तवमा शाक्ततन्त्र अन्तर्गत पर्ने तत्त्रहरुको संख्या अनगिन्ति रहेको छ। मध्यकाल र आधुनिक कालमा लेखिएका शाक्ततन्त्रहरुको सूची हेर्ने हो भने यसको संख्या हजारौं पुग्न सक्तछ। शाक्ततन्त्रसाहित्यको विशालता र लोकप्रीयताको कारणले जनमानसमा तन्त्र भन्नाले शाक्ततन्त्र नै बुऊने गरेको देखिन्छ।

\section{दशमहाविद्या / शिवका दशअवतारका शक्तिहरु}

दशमहाविद्या ज्ञानका प्रतिक हुन् र यिनीहरु प्रत्येकको आफ्नो अलग -अलग स्वरुप र कार्य हुन्छ। यिनीहरुलाई शिवका दशअवतारका शक्तिहरुको रुपमा पनि लिईन्छ जसको चर्चा तल गरिएको छ। यिनको उत्पत्तिको सम्बन्धमा दक्षप्रजापतिले छोरी सतीदेबी (सत्यदेबी) लाई आफुले गरेको यज्ञ अनुष्ठानमा नबोलाएपछि, सतीदेबी शिवजीले रोक्दा -रोक्दै पिता दक्षको यज्ञस्थलमा पुगिन्, त्यतिवेला पिता दक्षले सारै नमीठा शव्दले शिवको निन्दा गरे । उक्त निन्दा सहन नसकि त्यस अवसरमा सतीले वोलेका शब्दहरुका प्रतीक दशमहाविद्या उत्पत्ति भएको मानिन्छ र पछि तिनै दशमहाविद्यासमेतका शक्तिले दक्षको यज्ञ नष्ट गरेको मान्यता छ। महाभागवतमा दिईएको आख्यान अनुसार चाहिँ शिवले सतीलाई दक्षको यज्ञवाट जान रोकेका थिए, तर सती आफ्नो निश्चयमा अटल रहेर 'म प्रजापतिको यज्ञमा सम्मिलित भएर या त आफ्ना प्राणेश्वर पतिका लागि यज्ञ भाग प्राप्त गर्ने छु या यज्ञलाई नै विनष्ट पार्ने छु' भन्दै गर्दा सतीका आँखा राता राता भए र तिनले शिवलाई उग्र दृष्टिले हेर्न लागे। उनको शरीर कोधागिनले कालो निलो, महाभयानक र उग्र देखिन लाग्यो । त्यो समय महामायाको विग्रह प्रचण्ड तेजले तमतमा रहेको थियो। देवीको यो स्वरुप शिवको लागि पनि भयप्रद र प्रचण्ड 
थियो। देवीको यो विकराल महाभयानक रुप देखेर शिव भागे। भाग्न लागेका शिवलाई दशै दिशाहरुमा रोक्नको लागि सतीदेबीले आफ्ना अड़भूता देबीहरुलाई प्रकट गरिन्। देवीका यी स्वरुपा शक्तिहरु नै दशमहाविद्याहरु हुन् (जोशी, वि.सं. २०७० पृ. ३६६)। यसरी दशमहाविद्याहरु सतीदेबीबाट उत्पत्ति भएका तात्त्रिक देवीहरु मानिन्छन्। यिनीहरुको नाम कमश: १) काली २) तारा ३) षोडशी/त्रिपुरसुन्दरी ४) भुवनेश्वरी ४) भैरवी ६) छिन्नमस्ता ७) धूमावती ६) बगला ९) मातड़ी १०) कमला हुन् । शाक्ततन्त्र ग्रन्थहरुमा यी सवै देवीहरुको प्रतिमा लक्षण वताईएको छ जुन निम्नानुसार छन् (जोशी, वि.सं. २०७० पृ. ३६६- ३९१):-

१) काली- शवारुढ, महाभयानक शरीर भएकी, दश वाहुकी र वाहुरुमा खड्ग, चक्र, गदा, धनुष, वाण, शूल, भुशुण्डि, मस्तक, शंख, धारण गरेकी दश मुख र दश पाउकी हुनु पर्दछ। यिनको शिव स्वरुप पुरुष देवता महाकाल हुन् ।

२) तारा-सेतो कमल माथि विराजमान,कटि प्रदेशमा द्विपी (चितुवा)को चर्म धारण गरेकी, शवारुढ,सर्पका गहनाहरु लगाएकी, वाहुहरुमा कर्त्री, खड्ग,कपाल र निलोत्पलपुष्प धारण गरेकी, जटाजुट नागहरुद्वारा बद्ध हुन्छन् । यिनको शिव स्वरुप पुरुष देवता तार हुन् ।

३) षोडशी/त्रिपुरसुन्दरी/सुन्दरी/राजराजेश्वरी - सुन्दरीस्वरुपकी, चारवाहु, त्रिनेत्रकी ,शान्त मुद्रामा लेटिरहेका शदाशिव माथि रहेको कमलको आसनमाथि विराजमान रहेकी षोडशी देवीले वाहुहरुमा पाशT, अंकुश, धनुष, र वाण लिएका हुन्छन्। यिनको शिव स्वरुप पुरुष देवता षोडश हुन् ।

४) भुवनेश्वरी - उदाउन लागेको सूर्य जस्तो रक्तवर्णकी, त्रिनेत्रधारी, चन्द्रकलायुक्त मुकुट लगाएकी, वाहुहरु अभय र वरद मुद्रामा बाँकी दुईले अडुश र पाश धारण गरेका हुन्छन्। यिनको शिव स्वरुप पुरुष देवता भुवनेश्वर हुन् ।

४) भैरवी - उदाउन लागेको हजारौं सूर्यको समान कान्तियुक्त, त्रिनेत्रा, हिमांशु मुकुट धारण गरेकी, मुण्डमाला लाएकी, चार वाहुहरुमध्ये दुईवाहु अभय र बरद मुद्रामा र दुईवाहुले जपवटी र विद्या ग्रहण गरेका हुन्छन् । यिनको शिव स्वरुप पुरुष देवता भैरव हुन् ।

६) छिन्नमस्ता- शीर छिन्न (छिनिएकी) भएकी, मुण्डमाला लाएकी, कमल माथि,कामदेव र रतीको शरीरमाथि उभिएकी, नाभीमा योनीचक्र भएकी, दायाँ र वायाँ तमो र रजगुणका दुई देवीहरु सहचरीको रुपमा रहेका ,यी सहचरीको क्षुधा मेट्न कर्त्रिले स्वयं आफ्नै शीर काटेर तिनीहरुलाई रक्तपान गराई रहेकी र दिशाहरु नै यिनका वश्त्र रहेका हुन्छन् । यिनको शिव स्वरुप पुरुष देवता छिन्नमस्त हुन्।

७) धूमावती - विधवा रुपमा रहने, काकध्वज रथमा आरुढ, दुष्टा, कुटिल नेत्रलेयुक्त, खुला केशकी, कुटिल स्वभावा, भोलिएको स्तन भएकी, आकर्षण विहीन, कम्पितहस्ता लामो नासिकायुक्त हुन्छिन्। यिनको शिव स्वरुप पुरुष देवता धूमावान् हुन् । 
द) बगला/ बगलामुखी - रत्नमय सिंहासनमा वसेकी, पीतवर्णकी, पीतवर्ण कै वश्त्र, आभुषण र माला धारण गरेकी, एकवाहुमा शत्रुको जीट्वा र दोश्रोमा गदा लिएकी हुन्छिन् । यिनलाई चार वाहुकी र वाहुहरुमध्ये दुईवाहुले अक्षमाला र पुस्तक धारण गरेका र वाँकी दुईवाहुले अभय र वरदमुद्रा प्रदर्शन गरेका हुन्छन्। यिनको शिव स्वरुप पुरुष देवता बगलामुख हुन् ।

९) मातड़ी - रत्नमय सिंहासनमा वसेकी, एकपाउ कमलमाथि राखेर वीणा वजाइरहेकी, सँगै रहेको सुँगाको वोली सुनिरहेकी, चारवाहुहरुमा पाश, खड्ग, खेटक, अंकुश धारण गरेकी हुन्छिन् । यिनको शिव स्वरुप पुरुष देवता मातड़्र हुन् ।

१०) कमला - सुवर्ण तुल्य कान्तीमती, चार हात्तीका सुँडले सुवर्ण कलशद्वारा अभिषेक लिईरहेकी, चार वाहुकी र वाहुहरुमध्ये दुईवाहुले कमल समातेकी वाँकी दुईवाहुले अभय र वरदमुद्रा प्रदर्शन गरेकी हुन्छिन् । यिनको शिव स्वरुप पुरुष देवता कमल हुन् ।

शिवले सतीसित दशमहाविद्याहरुको परिचय सोधेको र सतीले तिनीहरुको परिचय गराएको प्रसड़्ग महाभागवतमा उल्लेख छ (जोशी, वि.सं. २०७० पृ. ३द६) ।

काठमाण्डौ उपत्यकामा दशमहाविद्याहरु पाटन क्षेत्रमा विशेष पुजिने परंपरा अभै सम्म रहेको छ। यहाँ टोल टोलमा यी देवीहरुको पीठ देख्न सकिन्छ भने, पाटन कुम्भेश्वर मन्दिर प्राङ्नणमा रहेको वगलामुखीको प्रशिद्धी विगत तीन दशक देखि वढ़दै गएको छ। यसरी नै भक्तपुर चाँगुनारायण मन्दिर प्राड्गणमा रहेको छिन्नमस्ता देवीको पनि निकै प्रशिद्धी रहेको छ।

\section{निष्कर्ष}

शाक्त परम्परा तन्त्र परम्पराको उपज हो र तन्त्र परम्परामा प्रचलित धार्मिक आस्था र मान्यताहरु लौकिक जनजीवनसँग सम्वद्ध भएर लोकरुची र लोकको अभीष्ट पूर्ति गर्ने उपाययुक्त साधनका रुपमा रहेका पाईन्छन् । यसरी तन्त्र मानिसका जीवनका व्यवहारिक प्रयोगहरुले भरिएको लौकिक तथा अलौकिक सिद्धि प्राप्त गर्ने उपायका रुपमा रहेको एउटा साधनाशास्त्र हो। त्यसैले लोकव्यवहारमा प्रचलित आस्था र जनविश्वास पनि तन्त्रवाद के एक अड्न हुन् । तात्त्रिक वाङमय वैदिक वाङमय जतिकै विशाल र प्राचीन रहेको छ। वैदिक वाङमय देखि लौकिक साहित्यसम्ममा तन्त्र र तन्त्रवादका धारणा भेटिन्छन् । यसवाट तान्त्रिक परम्परा वैदिक परम्परा सँगै समानान्तररुपमा विकसित भएको र समयको लामो कालखण्डमा दुवै परम्परा एकअर्कामा समन्वितरुपले र स्वतन्त्ररुपले प्रभाहित भएको पाईन्छ। यो विशाल तात्त्रिक वाङमय भित्र शाक्ततन्त्र एउटा शाखा हो र यो शाखा भित्र देवीका हजारौं स्वरुपहरु समेटिएका छन् । ती विविध स्वरुपहरु मध्ये तात्त्रिक देवीहरु दशमहाविद्या विशिष्ट मानिन्छन् र यिनीहरु सम्वन्वी हजारौं तान्त्रिक्रन्थहरु रचिएका छन् । मध्यकालको प्रारम्भ देखि तन्त्रवादले नेपालको धर्ममा ठूलो प्रभाव जमाउँदै आयो जसको परिणाम मातृदेवीको पूजाले जिउँदो कुमारीको रुप सम्म लिन पुग्यो र ती कुमारीको आजसम्म भक्तिपूर्वक पूजा हुन्छ। सर्वसाधारण नेपालीको दृष्टिमा कुमारी, गौरी, पार्वती, उमा, दुर्गा, काली, भगवती सवै स्वरुप एकै मातृदेवीका विभिन्न रुप हुन् र यहाँ दुर्गा, कुमारी, भगवती, 
हारती, अजिमा जोसुकै जुनसुकै देवकुलका भएपनि तिनको पूजा उही भक्तिभाव र उमझ्का साथ गरिन्छ। यहाँका धेरै चाडपर्व र पूजा-आरधना देवीहरुसंग सम्वन्धित रहेको छ वास्तवमा सिझ्रो नेपालाई नै एउटा शक्ति पीठको रुपमा लिनसकिन्छ (रेग्मी, वि.सं. २०३० पृ. १९५)। भगवती देवी सर्वव्यापक एकात्मक शक्ति भएपनि उहाँका विभिन्न स्वरुपहरु उपासनाका लागि प्रयुक्त हुन्छन्। ती मध्ये पनि दशमहाविद्याका स्वरुपका तात्त्रिक देवीहरु अत्यन्तै पवित्र मानिन्छन् ।

\section{सन्दर्भ ग्रन्थहरु}

उपाध्याय भट्ट, विद्यानाथ. (वि.सं. २०७४). नेपालमा शाक्त धर्म, दर्शनको परम्परा, शाक्त-उपासना-पत्र. पशुपति क्षेत्र विकाश कोषमा प्रस्तुत अप्रकासित शोधपत्र ।

कविराज, गोपीनाथ. (१९७२). तात्त्रिक साहित्य. लखनउ : हिन्दी समिति ।

कविराज, गोपीनाथ.(१९७७). तन्त्र और आगमशास्त्रोंका दिगदर्शन. पटना: विहार राष्ट्रभाषा परिषद

खनाल, मोहनप्रसाद. (बि.सं. २०प२२). नेपाली कला. ललितपुरः साभा प्रकाशन ।

ज व रा, धन शमशेर.(बि.सं.२०१६). तन्त्र-शास्त्र. काठमाण्डु : नेपाल एकेडेमी।

ज व रा, धन शमशेर.(बि.सं. २०३०). मातृकाक्षर-रहस्यम्. काठमाण्डौं : नेपाल राजकीय प्रज्ञा-प्रतिष्ठान ।

जोशी, हरिराम .(वि.सं. २०७०). प्रदीप अभिनव संस्कृति विश्वकोष. भक्तपुर : वर्कर्स पब्लिकेसन्स् ।

दीप, ध्रुवकृष्ण. (वि.सं. २०४२). हाम्रो संस्कृति हाम्रो ढुकुटी. ललितपुरः साभा प्रकाशन ।

पाण्डेय, राजवली .(१९६६). हिन्दु धर्म कोश. लखनउ : उत्तर प्रदेश हिन्दी संस्थान ।

प्रपन्नाचार्य, स्वामी. (वि.सं. २०७४). वेदमा के छ ? ललितपुर : साका प्रकाशन ।

प्रिस्टन,जेम्स.जे. (१९६०). कल्ट अफ द गडेसेस. न्यु डिल्ली : विकाश पव्लिसिड हाउस ।

बनर्जी, जे. (१९६६). पौराणिक एण्ड तात्त्रिक रिलिजन. कलकत्ता : युनिभर्सिटी अफ कलकत्ता ।

रेगमी ,जगदीश चन्द्र .(वि. सं. २०३०). नेपालको धार्मिक इतिहास. काठमाडौं : नेपाल राजकीय प्रज्ञा प्रतिष्ठान ।

रेग्मी ,जगदीश चन्द्र .(वि. सं. २०४३). पशुपति-गुह्यश्वरी माहात्म्य. काठमाडौं :नइ प्रकाशन ।

रेग्मी, डि. आर. (१९६६). मिडिएवल नेपाल भोलम २. कलकत्ता: एफ. के. एल. मुखोपाध्याय ।

लामिछाने, माधव प्रसाद. (वि.सं. २०७३). नेपाली समाजमा तन्त्रपरम्परा. काठमाडौं: नेपाल प्रज्ञा प्रतिष्ठान ।

वसिष्ठ, गौरिशंकर (टिकाकार). (वि.सं. २०४७). श्री दुर्गाशप्तशती (चण्डी). वाराणसी: श्री दुर्गा साहित्य भण्डार ।

वाङदेल, लैनसिंह. (१९९५). ईन्भेन्टरी अफ स्टोन स्क्लच्चर अफ द काठमाण्डू भ्याली. काठमाण्डों : रोएल नेपाल एकेडेमी। 
वाङदेल, लैनसिंह. (वि.सं. २०३९). प्राचीन नेपाली मूर्तिकलाको इतिहास. काठमाडौं : नेपाल राजकीय प्रज्ञा प्रतिष्ठान ।

वाङदेल, लैनसिंह. (१९६२). द अर्ली स्क्लप्चर अफ नेपाल. न्यूडिल्ली : विकाश पब्लिसिङ हाउस प्राइवेट लिमिटेड ।

वज्राचार्य, धनवज्र. (वि.सं. २०४३). लिच्छवि कालका अभिलेख. काठमाडौं : नेपाल र एशियाली अनुसन्धान केन्द्र। वज्राचार्य, धनवज्र. (वि.सं. २०६६). पूर्वमध्यकालका अभिलेख. काठमाडौं : नेपाल र एशियाली अनुसन्धान केन्द्र। शर्मा, लीलाधर.(१९९९). भारतीय संस्कृति कोश. नयाँदिल्ली : राजपाल एण्ड सन्स ।

स्लसर, एस.मेरी. (१९९६). नेपाल मण्डल, अ कल्चरल स्टडी अफ द काठमाण्डु भ्याली, भोलम दुई. काठमाण्डु : मण्डला बुक प्वाईन्ट।

स्लसर, एस. मेरी. (१९६२). नेपाल मण्डल, अ कल्चरल स्टडी अफ द काठमाण्डु भ्याली, भोलम एक. न्यू जर्सी : प्रिन्स्टन युनिभर्सिटी । 